\title{
The Associations of GH and GHR Genes with Carcass Components in Indonesian Kampung and Broiler Chicken Cross
}

\author{
I. Khaerunnisa ${ }^{a, b}$, Jakaria ${ }^{b}$, I. I. Arief ${ }^{b}$, C. Budiman ${ }^{b}$, \& C. Sumantri ${ }^{b}, c, *$ \\ aGraduate School, Animal Science and Technology Study Program, Bogor Agricultural University \\ bDepartment of Animal Production and Technology, Faculty of Animal Science, Bogor Agricultural University \\ Jalan Agatis, Kampus IPB Darmaga, Bogor 16680, Indonesia \\ cResearch Center for Bioresources and Biotechnology, Bogor Agricultural University \\ Jalan Kamper, Kampus IPB Darmaga, Bogor 16680, Indonesia \\ (Received 16-05-2017; Reviewed 19-07-2017; Accepted 31-07-2017)
}

\begin{abstract}
The chicken growth hormone (GH) and its receptor (growth hormone receptor, GHR) play important roles in chicken performances due to their crucial functions in growth. The variations of GH and GHR genes were then thought to be associated with the variations of the performances. This experiment was designed to identify the g.2248G $>\mathrm{A} \mathrm{GH}$ and the g.565G $>\mathrm{A}$ GHR loci polymorphisms and to evaluate their associations with carcass components in Kampung and broiler chicken cross. A total of 215 chickens including 4 chicken populations (Kampung, Cobb broiler, F1, and F2 Kampung $x$ broiler chicken cross) were screened to identify polymorphism using PCR-RFLP technique with EcoRV and Eco72I restriction enzyme for GH and GHR loci, respectively. The carcass components were recorded at 26 weeks of age on F2 Kampung and broiler chicken cross (42 chickens) for association study. Both the g.2248G>A GH and the g.565G>A GHR loci were polymorphic with two alleles ( $G$ and $A$ ) and three genotypes (GG, AG, and AA). The GG genotype and the G allele of GH locus were predominant in all chicken populations. While in GHR locus, the AA genotype and the A allele were found to be higher in all chicken populations. The association study showed that the g.565G $>\mathrm{A}$ GHR locus polymorphism had significant effect on carcass components, including live weight, carcass weight, breast weight, thighs weight, breast muscle weight, and thighs muscle weight. There was no significant association was found between the g.2248G>A GH genotype and carcass components. It could be concluded that the g.2248G $>$ A GH and the g.565G $>$ A GHR loci were polymorphic in Kampung and broiler chicken cross and the g.565G>A GHR locus was accosiated with carcass components. This g.565G>A GHR SNP might be an important candidate marker for chicken growth and muscle mass improvement.
\end{abstract}

Keywords: Kampung chicken cross, growth hormone, growth hormone receptor, gene polymorphisms, carcass

\section{ABSTRAK}

Hormon pertumbuhan dan reseptor hormon pertumbuhan memiliki peran penting dalam performa pertumbuhan ayam. Tujuan penelitian ini adalah mengidentifikasi keragaman gen hormon pertumbuhan (lokus g.2248G>A GH) dan gen reseptor hormon pertumbuhan (lokus g.565G $>\mathrm{A}$ GHR) dan mengevaluasi pengaruhnya pada komponen karkas pada ayam silangan Kampung dan broiler. Penentuan genotipe dilakukan pada 215 ekor ayam, yang terdiri atas 4 populasi (Kampung, ras pedaging strain $C o b b$, silangan F1 dan F2 Kampung $\mathbf{x}$ ras pedaging strain Cobb) menggunakan enzim pemotong EcoRV dan Eco72I masing-masing untuk fragmen lokus g.2248G>A GH dan lokus g.565G>A GHR. Analisis asosiasi dengan komponen karkas dilakukan pada populasi ayam silangan F2 Kampung $\mathbf{x}$ ras pedaging strain $C o b b$ umur 26 minggu. Kedua lokus tersebut bersifat polimorfik dengan dua alel yang ditemukan (alel A dan G) dan tiga genotipe (genotipe GG, AG, dan AA). Genotipe GG dan alel G pada lokus g.2248G>A GH ditemukan dalam frekuensi tertinggi di semua populasi yang diuji. Sementara pada lokus g.565G>A GHR, genotipe AA dan alel A ditemukan paling dominan. Analisis asosiasi menunjukkan adanya pengaruh signifikan pada lokus g.565G $>$ A GHR dengan komponen karkas (bobot hidup, bobot karkas, bobot potongan karkas bagian

${ }^{*}$ Corresponding author:

E-mail: ceces@ipb.ac.id; csumantri12@gmail.com 
dada, bobot potongan karkas bagian paha atas, bobot otot dada, dan bobot otot paha atas). Tidak ditemukan pengaruh signifikan pada lokus g.2248G>A GH dengan komponen karkas. Simpulan dari studi ini adalah lokus g.2248G>A GH dan g.565G>A GHR bersifat polimorfik pada ayam Kampung dan silangannya, serta terdapat asosiasi signifikan antara lokus g.565G >A GHR dengan komponen karkas ayam silangan F2 Kampung $\mathbf{x}$ ras pedaging strain Cobb. Hal ini menunjukkan bahwa lokus g.565G>A merupakan kandidat penciri komponen karkas ayam untuk tujuan peningkatan pertumbuhan dan massa otot.

Kata kunci: ayam silangan Kampung, growth hormone, growth hormone receptor, keragaman genetik, karkas

\section{INTRODUCTION}

Native chickens do not only contribute to the conservation of poultry genetic resources, but also play an important role in rural economies in most of the developing and undeveloped countries (Moharrery \& Mirzaei, 2014; Padhi, 2016). Kampung chicken is Indonesian native chicken, which can be found easily in rural area with strong economic and social relations to community (Nataamijaya, 2010). Zein \& Sulandari (2012) reported that Kampung chicken's population is getting expanded with high genetic diversity. However, growth is the main challenge for Indonesian native chicken production. By intensive rearing system, Indonesian Kampung chicken reaches slaughter weight in 4.5 months or more (FAO, 2008).

Improvement of the performance of Kampung chicken could be done by selection and crossbreeding or by utilization of both selection and crossbreeding (Sheng et al., 2013; Padhi, 2016). In order to improve the growth and carcass performance of Kampung chicken, an F2 intercross between Kampung and commercial broiler chicken was designed and then followed by selection based on genes controlling growth. Abdurrahman et al. (2016) reported that the local chicken crossbreds had lower fat and cholesterol contents due to a higher muscular contraction compared to modern breeds. Meanwhile, at the gene level, molecular genetics provides rapid and accurate identification and selection tools for individuals to improve their performances permanently (Fulton, 2008; Padhi, 2016). Furthermore, in poultry breeding program, selection in molecular approach could be done before the traits were expressed or shortly after hatching (Fulton, 2008).

Chicken growth is mainly regulated by the growth hormone $(\mathrm{GH})$. The chicken growth hormone is widely known as a major hormone that acts directly on chicken development and metabolism (Kim, 2010) and relates to egg production (Su et al., 2014; Vu \& Ngu, 2016). GH regulates a variety of physiological functions such as growth, body composition, egg production, aging, reproduction, sexual maturation, and functionality of the central nervous system (Gosney et al., 2012; Hrabia et al., 2008; Hull \& Harvey, 2014; Stephen et al., 2001). The GH/ IGF-1 signaling pathway is also believed to be capable of promoting growth of selected types of cancer (Kopchick et al., 2014). Activity of GH is greatly influenced by its receptors by forming the GH-GHR complex (Kuhn et al., 2002). Dimerization of GHR, which is caused by GH binding, activates a variety of signaling molecules that contributes to the GH-induced changes in enzymatic activity, transport function, and gene expression (Ciftci et al., 2013). Study of Xu et al. (2013) proposed that lacking of the GHR gene might be involved in dwarfism formation in chicken.

Studies in broiler chicken shows that the GH gene is located in chromosome 27, has $4.1 \mathrm{~kb}$ overall length and consists of five exons and four introns (Stephen et al., 2001; Nie et al., 2005). The GHR gene, which is located in chromosom $\mathrm{Z}$, has $4.0 \mathrm{~kb}$ length and consists of ten exons and nine introns (Nie et al., 2005). Nie et al. (2005) reported that 46 SNPs in GH gene and the g.2248G $>$ A GH $(\mathrm{G}+1705 \mathrm{~A})$ polymorphism in intron 3 had strong associations with growth traits in F2 White Recessive Rock and Xinghua chicken. A number of 33 SNPs in GHR gene was reported by Nie et al. (2005), and the g.565G>A GHR polymorphism was reported had significant associations with fatness and muscle fiber traits in Chinese local chickens (Lei et al., 2007). Studies in other poultries reported the associations of the GH gene with growth and carcass traits in Pitalah and Kumbang Janti Indonesian ducks (Yurnalis et al., 2017), Huoyan Chinese native goose (Zhang et al., 2014), and Japanese quail (Johari et al., 2013). In other farm animals, the GH gene was reported in cattle breeds (Dolmatova \& Ilyasov, 2011), pig (Ashok et al., 2014), salmonids fish (Kamenskaya et al., 2015), sheep (Jia et al., 2014), goat (An et al., 2011), camel (Shawki et al., 2015), and passerine bird (Arai \& Iigo, 2010). The effect of GH and GHR gene polymorphisms on carcass component in Kampung and broiler chicken cross has not been examined yet. The objectives of this study were to identify the g.2248G $>\mathrm{A}$ GH and the g.565G>A GHR loci polymorphisms using PCR-RFLP and to evaluate their effect on carcass components in Kampung and broiler chicken cross. This polymorphism information might serve as a platform for development of molecular marker in carcass and meat selections in chicken.

\section{MATERIALS AND METHODS}

\section{Animal and Phenotypic Data Collection}

Animal care procedures were approved by the Animal Care and Use Committee of Bogor Agricultural University (No. 22-2016 IPB). A number of 215 individuals consisting of 4 chicken populations: Kampung (49), commercial Cobb broiler (30), F1 Kampung x Cobb 
broiler cross (43), and F2 Kampung x Cobb broiler cross (93) were obtained from Animal Breeding and Genetics Division, Faculty of Animal Science, Bogor Agricultural University (IPB), Indonesia, were used in this experiment. The F2 cross was set by crossing individuals from the Kampung and commercial Cobb broiler lines as parental (P). Kampung chicken was selected as roosters, collected from traditional farmers in Ciawi, District of Bogor, West Java. Commercial Cobb broiler parent stock was used as hen. The F1 was generated by crossing Kampung and broiler lines. The F1s were then bred to generate F2. Blood sample from each individual (P, F1, and F2) was obtained from the wing vein and collected in tube containing EDTA. The experimental chickens were raised in the same environmental condition and had free access to feed and water.

F2 Kampung x Cobb broiler cross (42 chickens: 20 males and 22 females) were slaughtered at 26 weeks of age to collect carcass component data. Carcass component measurement included live weight, carcass weight, commercial cuts (breast, thighs, drum sticks, and wings) weights, muscle (breast muscle, thigh muscle, and drum sticks muscle) weights, and percentage of carcass, commercial cuts and muscles. The phenotypic of carcass measurement is provided in the Table 1.

\section{Genomic DNA Extraction}

Genomic DNA was isolated from blood. The DNA extraction protocol was performed according to

Table 1 . The phenotype of carcass measurement

\begin{tabular}{ccccc}
\hline Trait & Mean $(\mathrm{g})$ & $\begin{array}{c}\text { Standard } \\
\text { deviation }(\mathrm{g})\end{array}$ & Min $(\mathrm{g})$ & Max $(\mathrm{g})$ \\
\hline LW & $2,195.811$ & 488.007 & 1124 & 2987 \\
CW & $1,457.976$ & 358.350 & 715 & 2253 \\
BW & 379.381 & 109.381 & 180 & 640 \\
TW & 267.929 & 71.956 & 132 & 393 \\
DW & 256.143 & 66.520 & 133 & 370 \\
WW & 203.381 & 46.740 & 117 & 325 \\
BMW & 271.000 & 88.645 & 120 & 511 \\
TMW & 192.690 & 54.634 & 96 & 331 \\
DMW & 165.024 & 46.206 & 90 & 273 \\
\hline
\end{tabular}

Note: $\mathrm{LW}=$ Live Weight; $\mathrm{CW}=$ Carcass Weight; $\mathrm{BW}=$ Breast Weight; TW= Thighs Weight; DW= Drum Sticks Weight; WW= Wings Weight; $\mathrm{BMW}=$ Breast Muscle Weight; $\mathrm{TMW}=$ Thighs Muscle Weight; DMW= Drum Sticks Muscle Weight.
Sambrook \& Russel (2001) with minor modification. Briefly, each $20 \mu \mathrm{L}$ of blood sample was added with $800 \mu \mathrm{L}$ RBC lysis buffer, homogenized, and centrifuged (800 rpm) for $5 \mathrm{~min}$. Then, the supernatant part was removed. The precipitation part was added with 40 $\mu \mathrm{L} 10 \%$ SDS, $10 \mu \mathrm{L}$ Proteinase K $5 \mathrm{mg} / \mathrm{mL}$, and $300 \mu \mathrm{L}$ $1 \times$ STE, and slowly shaken at $55^{\circ} \mathrm{C}$ for $2 \mathrm{~h}$. Then, each sample was added with $400 \mu \mathrm{L}$ phenol solution, 400 $\mu \mathrm{L}$ CIAA, and $40 \mu \mathrm{L} \mathrm{NaCl} \mathrm{5M}$, and slowly shaken at room temperature for an hour, and centrifuged (12000 $\mathrm{rpm}$ ) for $5 \mathrm{~min}$. About $400 \mu \mathrm{L}$ liquid from top layer was removed into a new tube and added with $800 \mu \mathrm{L} 96 \%$ EtOH and $40 \mu \mathrm{L} \mathrm{NaCl} 5 \mathrm{M}$. Then, the sample was frozen overnight. DNA molecule was centrifuged (12000 rpm) for $5 \mathrm{~min}$, and the supernatant part was discarded. For the DNA precipitation, the pellet was air dried and 100 $\mu \mathrm{L} 80 \%$ TE was added. DNA sample was frozen stored for long term usage.

\section{Amplification and Genotyping}

Specific fragments of GH and GHR genes were produced with the polymerase chain reaction (PCR) method using thermocycler machine (GeneAmp® PCR System 9700, Applied Bio SystemsTM, Foster City, USA). Primers (Table 2) were designed using Primer Designing Tool (http://www.ncbi.nlm.nih.gov/tools/ primer-blast/). The PCR process was run with 35 cycles consisting of denaturation at $95^{\circ} \mathrm{C}$ for $10 \mathrm{~s}$, annealing at $60-61^{\circ} \mathrm{C}$ for $20 \mathrm{~s}$, and extension at $72^{\circ} \mathrm{C}$ for $30 \mathrm{~s}$. Amplification was performed with a total volume of 25 $\mu \mathrm{L}$ containing $50 \mathrm{ng} / \mu \mathrm{L}$ DNA sample, $0.5 \mathrm{pmol}$ primer, 0.5 unit GoTaq Green Master Mix (Promega, Madison, USA), and water.

Genotyping was done using a restriction fragment length polymorphism (RFLP). PCR product and restriction enzyme (Thermo Fisher Scientific, EU, Lithuania) were incubated at $37^{\circ} \mathrm{C}$ for $12 \mathrm{~h}$. Genotype was visualized through $2 \%$ agarose gel electrophoresis (v/w), which was stained with FluoroSafe DNA Staining $\left(1^{\text {st }}\right.$ Base, Singapore) above UV Transilluminator (Alpha Imager, Alpha Innotech, Santa Clara, USA). Primers annealing position and restriction site of $\mathrm{GH}$ and GHR were shown in Figures 1 and 2, respectively. To confirm the mutations occurred, direct sequencing was performed on an ABI-PRISM3730 sequencer ( $1^{\text {st }}$ Base, Singapore) in three samples per genotype per locus.

Table 2. The primer sequences

\begin{tabular}{|c|c|c|c|c|c|c|c|}
\hline Gene & $\begin{array}{l}\text { SNP target } \\
\text { position }\end{array}$ & Primer sequence $\left(5^{\prime}-3^{\prime}\right)^{*}$ & $\begin{array}{c}\text { PCR } \\
\text { product }\end{array}$ & Annealing & $\begin{array}{c}\text { Restriction } \\
\text { enzyme }\end{array}$ & $\begin{array}{l}\text { Product pattern } \\
\text { (Genotype) }\end{array}$ & Reference \\
\hline $\mathrm{GH}$ & $\begin{array}{c}\text { Intron } 3 \\
(\mathrm{~g} .2248 \mathrm{G}>\mathrm{A} \\
\mathrm{GH})\end{array}$ & $\begin{array}{l}\text { F: ATGTCTCCACAGGAACGCAC } \\
\mathrm{R}: \text { GCTCTGTAAGCTGAGCACCAC }\end{array}$ & $339 \mathrm{bp}$ & $60^{\circ} \mathrm{C}$ & $\begin{array}{c}\text { EcoRV } \\
(\mathrm{GAT} \mid \mathrm{ATC})\end{array}$ & $\begin{array}{l}\text { GG: } 339 \mathrm{bp} \\
\text { AA: } 148 \text { and } 191 \mathrm{bp} \\
\text { AG: } 148,191 \text {, and } 339 \mathrm{bp}\end{array}$ & $\begin{array}{l}\text { Nie et al. } \\
(2005)\end{array}$ \\
\hline GHR & $\begin{array}{l}\text { Intron } 5 \\
(\mathrm{~g} .565 \mathrm{G}>\mathrm{A} \\
\text { GHR })\end{array}$ & $\begin{array}{l}\text { F: TCTGCAGAGTCGGGATATTTAGCA } \\
\text { R: ACTCTCCATCAGAATTTATCCCG }\end{array}$ & $326 \mathrm{bp}$ & $61{ }^{\circ} \mathrm{C}$ & $\begin{array}{c}E c o 72 \mathrm{I} \\
(\mathrm{CACIGTG})\end{array}$ & $\begin{array}{l}\text { AA: } 326 \mathrm{bp} \\
\text { GG: } 114 \text { and } 212 \mathrm{bp} \\
\text { AG: } 114,212 \text {, and } 326 \mathrm{bp}\end{array}$ & $\begin{array}{l}\text { Lei et al. } \\
(2007)\end{array}$ \\
\hline
\end{tabular}

Note: ${ }^{*} \mathrm{~F}=$ Forward, $\mathrm{R}=$ reverse 


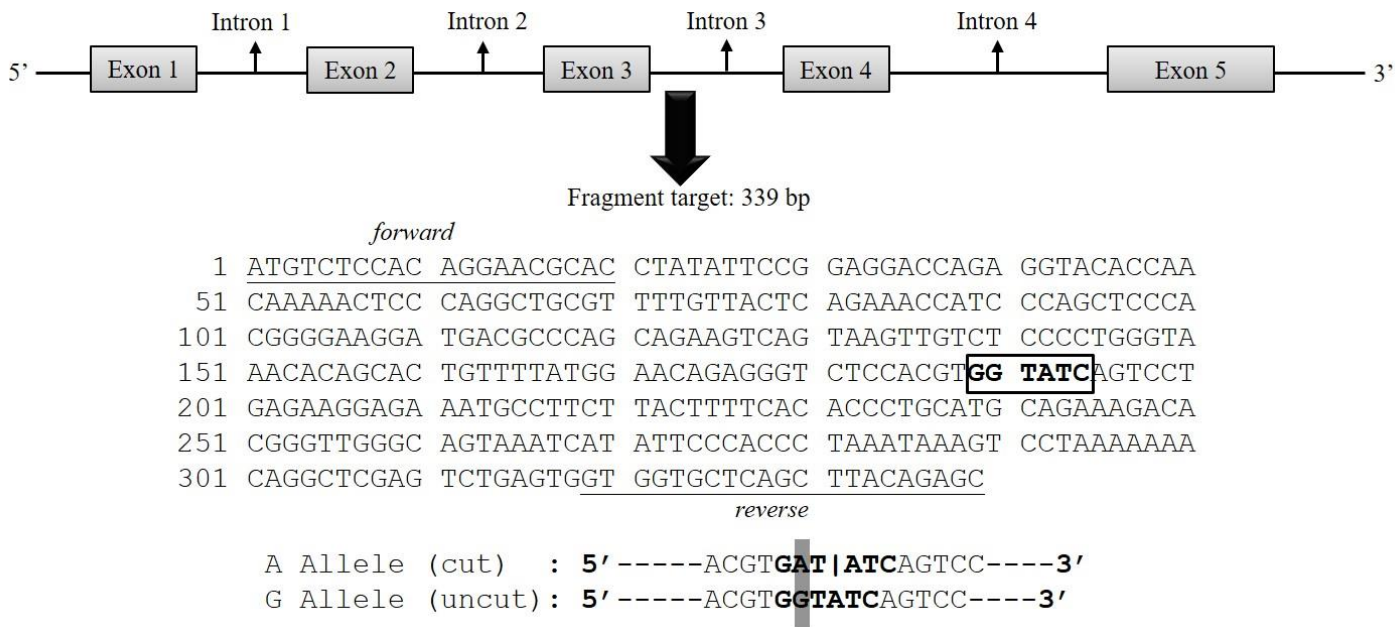

Figure 1. Fragment target of the g.2248G>A GH locus located in intron 3, and resulted the A and G allele. Underline shows forward and reverse primer annealing position; bold shows EcoRV restriction site (GenBank accession number: AY461843.1).

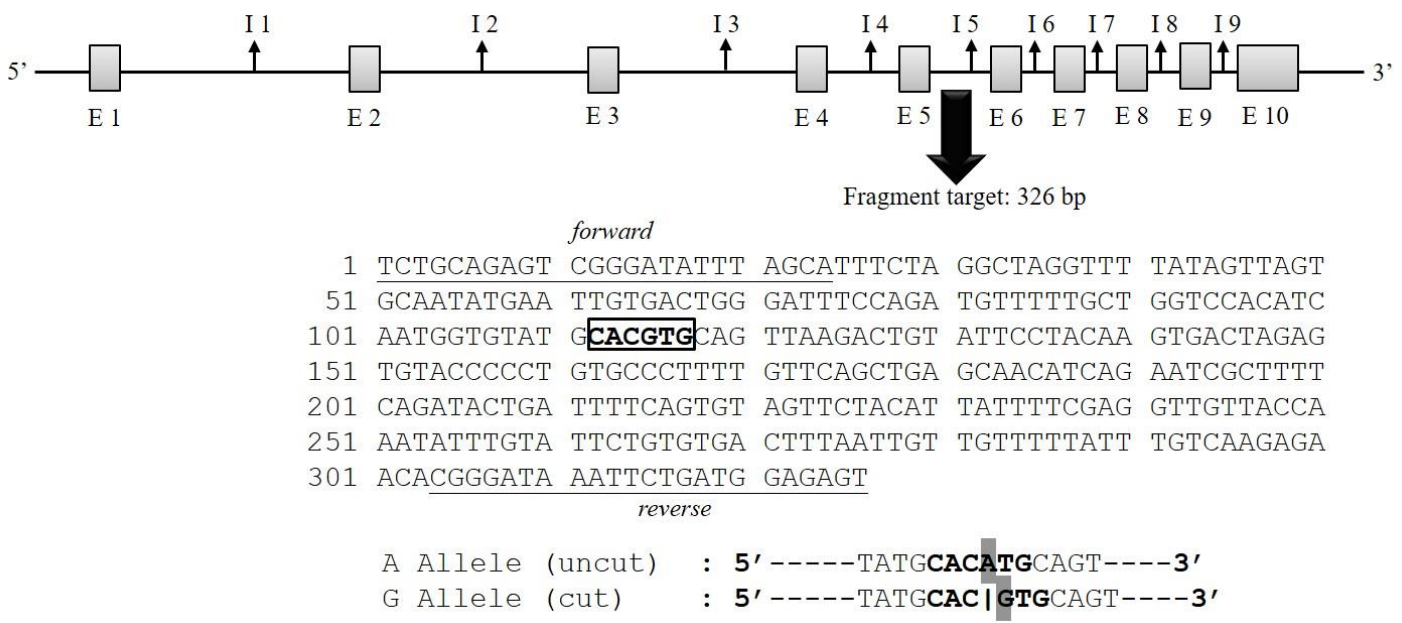

Figure 2. Fragment target of the g.565G>A GHR locus located in intron 5, and resulted the A and G allele. Underline shows forward and reverse primer annealing position; bold shows Eco72I restriction site; $\mathrm{E}=$ exon; I= intron (GenBank accession number: AJ506750.1).

\section{Data Analysis}

Polymorphism information and sequencing. Polymorphism parameters (genotype frequency, allele frequency, and the Hardy-Weinberg Equilibrium) were analyzed according to Nei \& Kumar (2000). All sequence results (ABI trace files) were analyzed in Molecular Evolutionary Genetic Analysis (MEGA) 6.0 according to Tamura et al. (2013) and BioEdit (Hall, 2011). The Basic Local Alignment Search Tool (BLAST) was used to identify similarity (homology) with genes data in GenBank (www.ncbi.nhl.nih.gov./BLAST).

Statistical analysis. The association of genotype with carcass components was analyzed using SAS GLM procedure (SAS Institute, 2008) and Duncan multiple range test. The genetic effects were analyzed using this model:

$$
\mathrm{y}_{\mathrm{ijk}}=\mu+\mathrm{S}_{\mathrm{i}}+\mathrm{G}_{\mathrm{j}}+\varepsilon_{\mathrm{ijk}}
$$

where $y_{i j k}$ was the observed phenotypic trait (carcass components) for $\mathrm{k}^{\text {th }}$ individual with $\mathrm{i}^{\text {th }}$ sex ( $\mathrm{i}=$ male and female) and $j^{\text {th }}$ genotype ( $j=A A, A G$, and $\left.G G\right), \mu$ was the overall mean, $S_{i}$ was the genetic effect of $i^{\text {th }}$ sex, $G$ was the genetic effect of $\mathrm{j}^{\text {th }}$ genotype, and $\varepsilon_{\mathrm{ijk}}$ was the normally distributed residual error.

\section{RESULTS}

\section{Polymorphisms of GH $\mid$ EcoRV and GHR $\mid$ Eco72I Loci}

The partial fragment of GH and GHR genes in all individuals were successfully amplified and showed a 339 and 326 bp bands, respectively (Figure 3). The lengths of PCR products were in good agreements with the reference sequences (GenBank accession number: AY461843.1 and AJ506750.1 for GH and GHR, respectively). Genotyping analysis of GH locus was performed 
using EcoRV restriction enzyme. This genotyping identified two alleles (A and $\mathrm{G}$ ) and three genotypes (AA, AG, and GG). The A allele was indicated by 191 and $148 \mathrm{bp}$ bands (restricted), while the $G$ allele was indicated by $339 \mathrm{bp}$ (unrestricted, Figure 4). Mutation was found in $190 \mathrm{bp}$ from $\mathrm{G}$ to A nucleotide, (Figure 5). According to GenBank (accession number: AY461843.1), this SNP is located in g.2248G>A GH. Moreover, Eco72I enzyme was used for genotyping of GHR locus. The genotyping of GHRIEco72I locus generated the same allele and genotype with GHIEcoRV locus. The A allele was indicated by a 326 bp (unrestricted), while the $G$ allele was indicated by 212 and 114 bp (restricted, Figure 4). Mutation from $G$ to $A$ nucleotide was occurred in the position of $115 \mathrm{bp}$ (Figure 6). According to GenBank (accession number: AJ506750.1), this SNP is located in g.565G>A GHR.

All chicken populations were polymorphic for both GH and GHR loci (Table 3). The GG genotype and the $\mathrm{G}$ allele of $\mathrm{GH}$ locus were predominant in all chicken populations. The AA genotype was barely found (0.005) in overall population. The AA genotype was only found in Cobb population (0.033), not in Kampung, F1, and F2 chicken populations. While in GHR locus, the AA genotype and the A allele were found to be higher in all chicken populations. The $\mathrm{x}^{2}$ analysis of GH locus showed that all chicken populations were in the HardyWeinberg equilibrium. In the GHR locus, the Cobb broiler and F2 cross chicken populations were in the Hardy-Weinberg disequilibrium. This result indicated that the allele and genotype frequencies were not con- stant from generation to generation in these two populations (Allendorf et al., 2013).

\section{Effect of Gene Polymorphism on Carcass Components}

Association analyses showed that the g.565G $>A$ GHR locus polymorphism had significant effect on chicken carcass components, but no significant associations between g.2248G $>$ A GH genotype and carcass components were observed (Table 4). The GG genotype of g.565G>A GHR locus had higher live weight, carcass weight, breast weight, thigh weight, breast muscle weight, and thigh muscle weight than the AA genotype $(\mathrm{P}<0.05)$ in F2 Kampung x Cobb broiler chicken cross. No significant differences were found in carcass percentage, commercial cuts percentages, and muscle weight percentages.

\section{DISCUSSION}

The essential roles of $\mathrm{GH}$ and GHR genes in chicken have been explored since decades for improving meat productivity of chicken. The GH molecule has two binding sites which each interacts with the extracellular region of the performed GHR dimer. This binding leads a functionally dimerized complex that induces intracellular signaling (Kopchick, 2016; List et al., 2013). The GH-GHR complexes are then resulted in the endoplasmic reticulum (van den Eijnden \& Strous, 2007). This complexes travel to the cell surface and activate the JAK2 via the STAT5/MAPK pathway (Sedek et al., 2014).
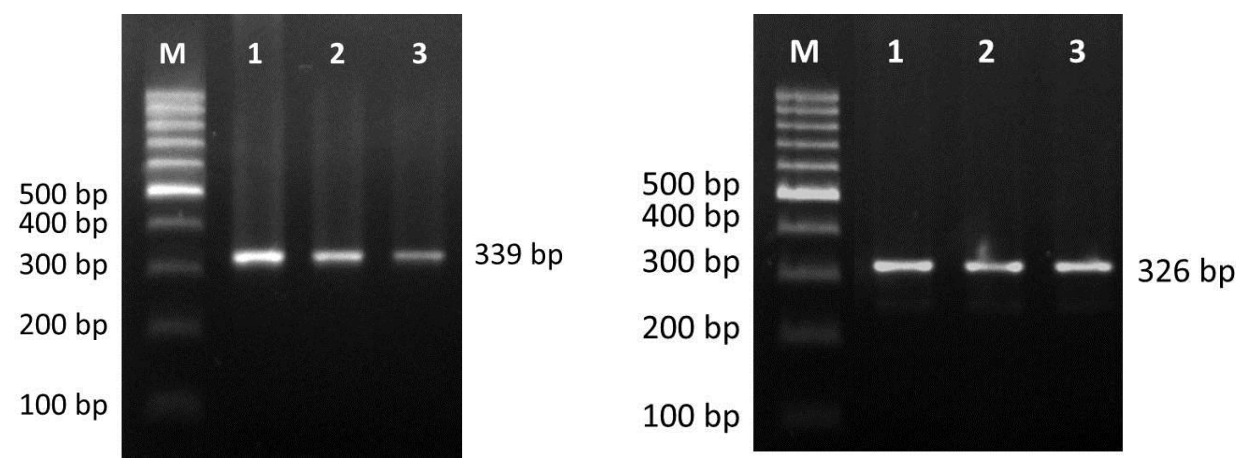

Figure 3. Visualization of GH (left) and GHR (right) fragment genes amplification in 1.5\% agarose gel. (M= marker; $1-3=$ sample).
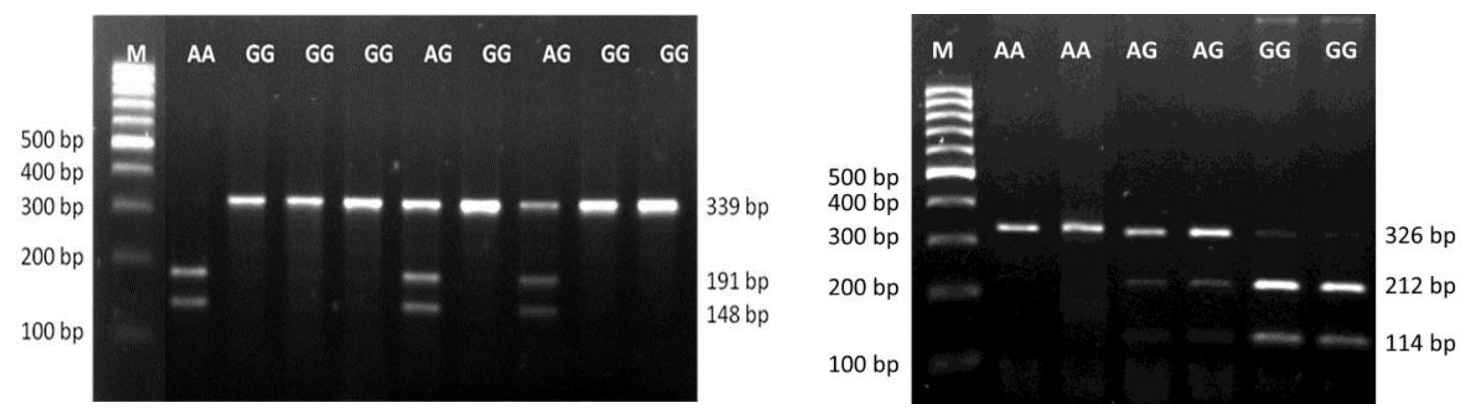

Figure 4. Visualization of GH | EcoRV (left) and GHR | Eco72I (right) genotyping in 2\% agarose gel (M=marker; GG, AG, AA = genotype) 


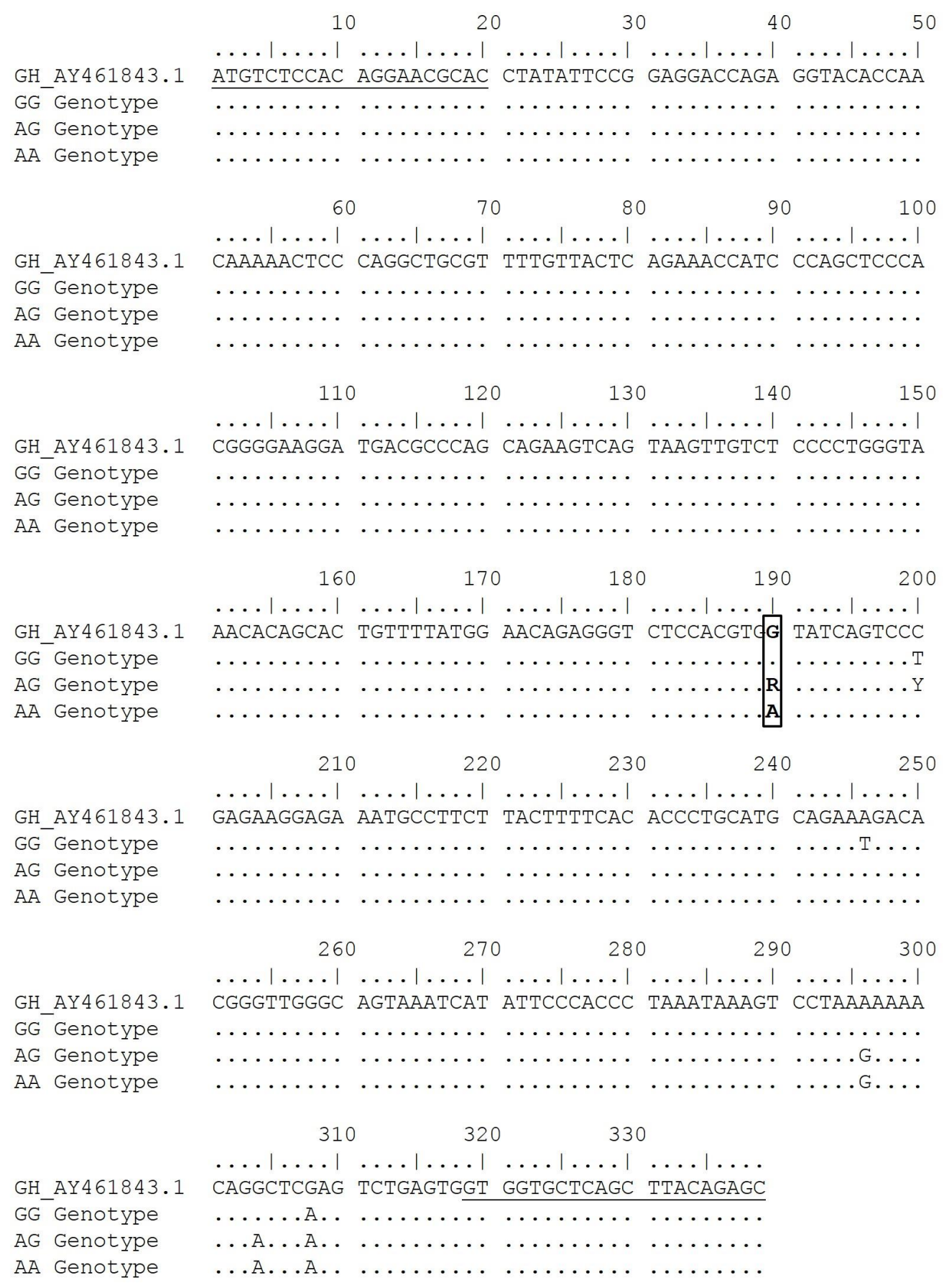

Figure 5. Partial intron 3 nucleotide sequence of chicken GH gene. Underline shows forward and reverse primer annealing positions; bold shows EcoRV restriction sites; box shows g.2248G>A GH SNP target (GenBank accession number: AY461843.1) .

Kim et al. (2010) explain that the GH-GHR complexes activate hepatic IGF-I secretion, which stimulates the differentiation and proliferation of bone and muscle cell. Our study in the GHIEcoRV genotyping generated the GG genotype predominantly (0.749), the AG genotype as a second majority (0.247), and almost no AA genotype was found (0.005) in overall population. The AA genotype was detected only in $\mathrm{Cobb}$ broiler population in a very low frequency. Similarly, in the F2 population generated from White Recessive Rock and Xinghua chicken, 18 chickens with the AA genotype were found from total 451 chickens (AA genotype freq=0.04; Nie et al., 2005). Higher GG genotype frequency was also reported by Lei et al. (2007) in Xinghua (0.67) and White Plymouth Rock (1.00) chickens, Zhang et al. (2007) in Mountainous Black-Bone (0.70), Caoke (0.70), Sanhuang (0.73), and a commercial crossbred (0.83) chickens, AlKhatib \& Al-Hassani (2016) in Cobb (0.47) and Hubbard (0.61) chickens, and Anh et al. (2015) in broiler x Khai Mook Esarn chicken (0.65).

Association study was performed at 26 weeks of age, when Kampung chicken reached the sexual 


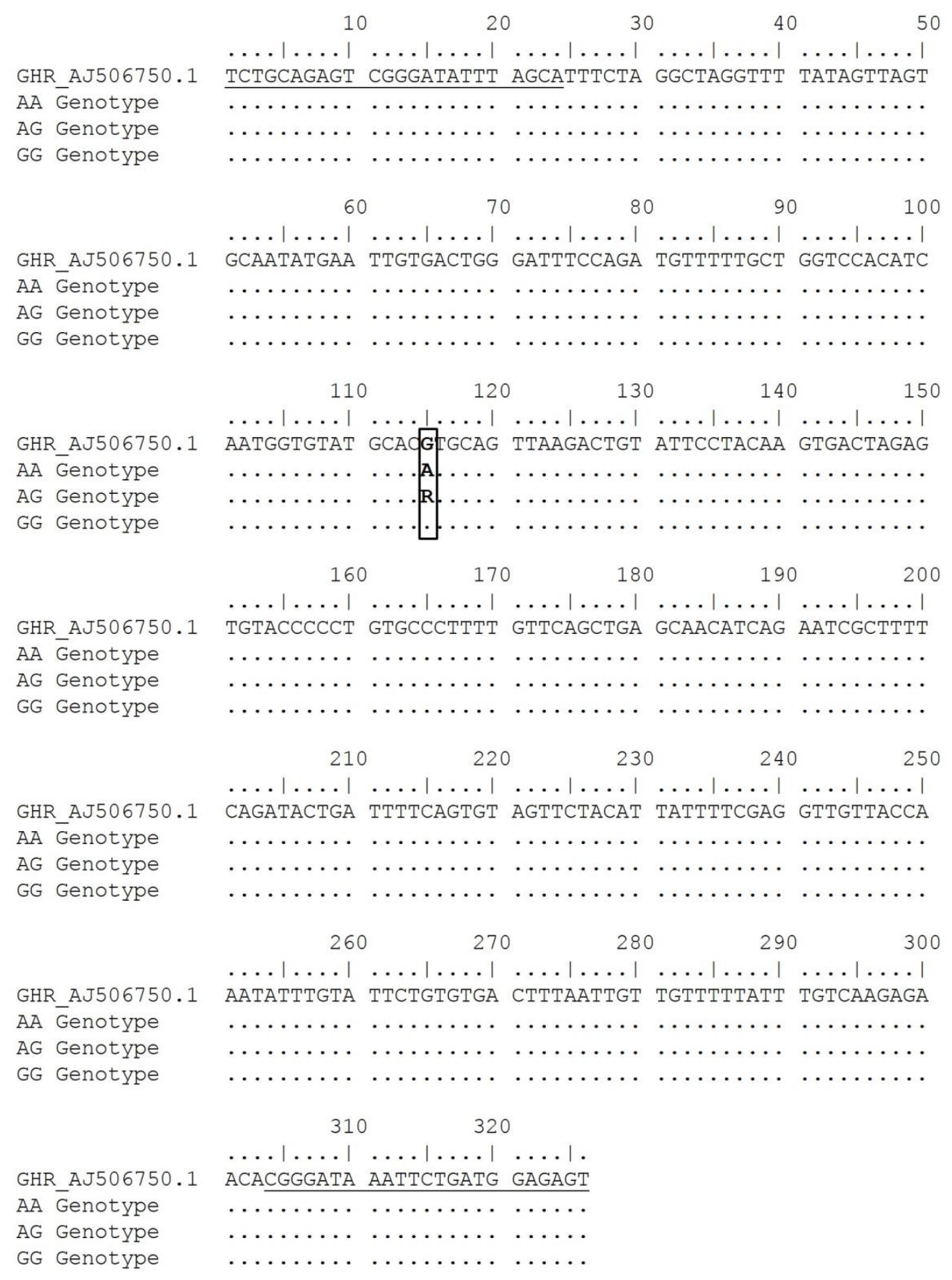

Figure 6. Partial intron 5 nucleotide sequence of chicken GHR gene. Underline shows forward and reverse primer annealing positions; bold shows Eco72I restriction sites; box shows g.565G>A GHR SNP target (GenBank accession number: AJ506750.1).

maturity in semi-intensive rearing system (Yuwanta \& Fujihara, 2000). At the age of 26 weeks, chicken growth is in the stationary phase. Thus, in this phase, chicken has reached the maximum growth (Knízetová et al., 1995). Results of our study showed no significant effect between the g.2248G>A GH polymorphism and chicken carcass components. This result was in line with Zhang et al. (2007) in the Chinese indigenous chicken populations. Different to our findings, Nei et al. (2005) and Anh et al. (2015) found any associations of this SNP with chicken growth and carcass traits. Nie et al. (2005) reported that the AA genotype had positive effects (higher body weight, shank length, and ADG) in a F2 population derived from a cross of a fast-growing line, White Recessive Rock, and a slow-growing line, Xinghua. However, Anh et al. (2015) found that the AA genotype negatively affected carcass traits (lower body weight and ADG) in Thai broiler chicken. From those various studies, effects of this g.2248G $>$ A GH polymorphism in different chicken breeds generated varied results. Kansaku et al. (2008) presumed that this indicated the various involvements of $\mathrm{GH}$ in production parameters. Moreover, Harvey (2013) concludes from large literature that pituitary GH has no effect on avian growth. 
Table 3. The polymorphism information of the g.2248G>A GH and the g.565G>A GHR loci in Kampung chicken and cross

\begin{tabular}{|c|c|c|c|c|c|c|c|}
\hline \multirow{2}{*}{ Locus/ Population } & \multirow{2}{*}{$\mathrm{n}$} & \multicolumn{3}{|c|}{ Genotype frequency } & \multicolumn{2}{|c|}{ Allele frequency } & \multirow{2}{*}{$\chi^{2}$} \\
\hline & & GG & AG & AA & $\mathrm{G}$ & A & \\
\hline \multicolumn{8}{|l|}{ GHIEcoRV } \\
\hline 1. Kampung & 49 & $0.939(43)$ & $0.061(3)$ & $0.000(0)$ & 0.969 & 0.031 & 0.049 \\
\hline 2. Cobb Broiler & 30 & $0.600(18)$ & $0.367(11)$ & $0.033(1)$ & 0.783 & 0.217 & 0.193 \\
\hline 3. F1 Kampung $\times$ Cobb Broiler Cross & 43 & $0.558(24)$ & $0.442(19)$ & $0.000(0)$ & 0.779 & 0.221 & 3.458 \\
\hline 4. F2 Kampung $\times$ Cobb Broiler Cross & 93 & $0.785(73)$ & $0.215(20)$ & $0.000(0)$ & 0.892 & 0.108 & 1.350 \\
\hline Overall population & 215 & $0.749(161)$ & $0.247(53)$ & $0.005(1)$ & 0.872 & 0.128 & 2,369 \\
\hline \multicolumn{8}{|l|}{ GHR|Eco72I } \\
\hline 1. Kampung & 49 & $0.000(0)$ & $0.020(1)$ & $0.980(48)$ & 0.010 & 0.990 & 0.005 \\
\hline 2. Cobb Broiler & 30 & $0.300(9)$ & $0.067(2)$ & $0.633(19)$ & 0.333 & 0.667 & $21.675^{*}$ \\
\hline 3. F1 Kampung $\times$ Cobb Broiler Cross & 43 & $0.000(0)$ & $0.372(16)$ & $0.628(27)$ & 0.186 & 0.814 & 2.247 \\
\hline 4. F2 Kampung $\times$ Cobb Broiler Cross & 93 & $0.140(13)$ & $0.194(18)$ & $0.667(62)$ & 0.237 & 0.763 & $20.035^{*}$ \\
\hline Overall population & 215 & $0.102(22)$ & $0.172(37)$ & $0.726(156)$ & 0.188 & 0.812 & $41.095^{*}$ \\
\hline
\end{tabular}

Note: $\mathrm{n}=$ number of sample, ${ }^{*}=$ significantly different $\left(\chi^{20.05}=3.84\right)$

Table 4. The association of the g.2248G>A GH and the g.565G>A GHR loci polymorphisms and carcass components in F2 Kampung $\mathrm{x}$ broiler chicken cross

\begin{tabular}{|c|c|c|c|c|c|}
\hline \multirow{2}{*}{ Trait } & \multicolumn{2}{|c|}{ g.2248G>A GH } & \multicolumn{3}{|c|}{ g.565G>A GHR } \\
\hline & GG $(n=31)$ & $\mathrm{AG}(\mathrm{n}=11)$ & $\mathrm{GG}(\mathrm{n}=4)$ & $\mathrm{AG}(\mathrm{n}=10)$ & $\mathrm{AA}(\mathrm{n}=28)$ \\
\hline LW (g) & $2211.53 \pm 505.44$ & $2151.52 \pm 455.08$ & $2598.50 \pm 51.08^{a}$ & $2286.05 \pm 431.80^{\mathrm{ab}}$ & $2106.06 \pm 513.62^{\mathrm{b}}$ \\
\hline CW (g) & $1471.35 \pm 376.01$ & $1420.27 \pm 316.61$ & $1746.25 \pm 75.08^{\mathrm{a}}$ & $1570.30 \pm 342.30^{\mathrm{ab}}$ & $1376.68 \pm 362.60^{b}$ \\
\hline BW (g) & $389.94 \pm 117.60$ & $349.64 \pm 79.03$ & $491.00 \pm 81.05^{\mathrm{a}}$ & $433.50 \pm 103.51^{\mathrm{ab}}$ & $344.11 \pm 98.21^{\mathrm{b}}$ \\
\hline TW (g) & $269.13 \pm 73.87$ & $264.55 \pm 69.56$ & $328.25 \pm 37.12^{\mathrm{a}}$ & $283.10 \pm 58.56^{\mathrm{ab}}$ & $253.89 \pm 75.75^{\mathrm{b}}$ \\
\hline DW $(g)$ & $259.26 \pm 66.80$ & $247.36 \pm 68.11$ & $285.75 \pm 44.62$ & $277.90 \pm 56.28$ & $244.14 \pm 70.62$ \\
\hline WW (g) & $204.29 \pm 47.67$ & $200.82 \pm 46.15$ & $231.25 \pm 32.44$ & $218.50 \pm 48.46$ & $194.00 \pm 46.11$ \\
\hline BMW (g) & $279.87 \pm 95.42$ & $246.00 \pm 63.00$ & $341.00 \pm 48.96^{\mathrm{a}}$ & $305.10 \pm 97.98^{\mathrm{ab}}$ & $248.82 \pm 82.46^{\mathrm{b}}$ \\
\hline TMW (g) & $196.68 \pm 58.67$ & $181.45 \pm 41.53$ & $241.50 \pm 48.59^{a}$ & $198.70 \pm 44.41^{\mathrm{ab}}$ & $183.57 \pm 56.22^{\mathrm{b}}$ \\
\hline DMW (g) & $167.19 \pm 46.20$ & $158.91 \pm 47.90$ & $191.50 \pm 31.37$ & $172.40 \pm 37.59$ & $158.61 \pm 49.95$ \\
\hline $\mathrm{CP}(\%)$ & $66.27 \pm 5.35$ & $66.03 \pm 3.60$ & $67.24 \pm 3.79$ & $68.44 \pm 3.60$ & $65.26 \pm 5.27$ \\
\hline BP (\%) & $26.56 \pm$ & $24.60 \pm$ & $28.20 \pm 5.29$ & $27.59 \pm$ & $25.19 \pm$ \\
\hline TP (\%) & $18.31+$ & $18.49 \pm$ & $18.85 \pm 2.54$ & $18.09 \pm$ & $18.38 \pm$ \\
\hline DP (\%) & $17.74 \pm$ & $17.27 \pm$ & $16.37 \pm 2.53$ & $17.80 \pm$ & $17.73 \pm$ \\
\hline WP (\%) & $14.08 \pm$ & $14.16 \pm$ & $13.20 \pm 1.35$ & $13.94 \pm$ & $14.29 \pm$ \\
\hline BMP (\%) & $18.97 \pm$ & $17.27 \pm$ & $19.60 \pm 3.41$ & $19.24 \pm$ & $18.12 \pm$ \\
\hline TMP (\%) & $13.33 \pm$ & $12.99 \pm$ & $13.85 \pm 2.88$ & $12.68 \pm$ & $13.36 \pm$ \\
\hline $\operatorname{DMP}(\%)$ & $11.39 \pm$ & $11.08 \pm$ & $10.95 \pm 1.67$ & $11.02 \pm$ & $11.46 \pm$ \\
\hline
\end{tabular}

Note: LW=Live Weight; CW=Carcass Weight; BW=Breast Weight; TW=Thighs Weight; DW=Drum Sticks Weight; WW=Wings Weight; BMW=Breast Muscle Weight; TMW=Thighs Muscle Weight; DMW=Drum Sticks Muscle Weight; $\mathrm{CP}=$ Carcass Percentage; $\mathrm{BP}=\mathrm{Breast}$ Percentage; TP=Thighs Percentage; DP=Drum Sticks Percentage; WP=Wings Percentage; BMP=Breast Muscle Percentage; TMP=Thighs Muscle Percentage; DMP=Drum Sticks Muscle Percentage; $\mathrm{n}=$ number of sample; different superscript indicates significantly difference at the $\mathrm{P}<0.05$ levels for chickens with different genotypes of a given locus.

Polymorphism study in the g.565G>A GHR locus found that the AA genotype had the highest frequency (0.726) than the AG (0.172) and GG (0.102) in overall population. Similar result was reported in Vietnamese (0.86, Khoa et al., 2013), Noi (1.00, Khoa et al., 2013), Xinghua (1.00, Lei et al., 2007), and White Plymouth Rock (1.00, Lei et al., 2007) chickens. Ouyang et al. (2008) could not detect the g.565G $>$ A GHR polymorphism using DHPLC detection in Leghorn layer, White Recessive Rock broiler, Taihe Silkies, and Xinghua chickens.
This study evidenced the association of the g.565G>A GHR genotype with live weight, carcass weight, breast weight, thigh weight, breast muscle weight, and thigh muscle weight, for the first time. Our finding proposed that the GG genotype of the g.565G>A GHR had positive effect on chicken carcass and yielded proportional body composition. The inhibition of normal human and animal skeletal muscle growths and fat depositions was reported to be caused by mutation in GHR gene by causing the inhibition of GH signal transduction (Lin et 
al., 2012). However, the molecular mechanism of GHR introns and its effect on muscle growth in chicken is unclear. It is believed that the genetic potential of Kampung chicken can be improved through crossbreeding and selection. In this study, the $G$ allele of the g.565G>A GHR locus tends to have a positive effect on body and carcass weight in F2 Kampung and broiler chicken cross. This locus can be recommended as a good candidate to select chickens with better growth and heavier carcass weights. However, further analysis in larger populations and study on the gene expression and protein level is necessary to be proven to reinforce this hypothesis.

\section{CONCLUSION}

This study investigated the polymorphisms of $\mathrm{GH}$ and GHR genes and emphasized that the g.565G $>A$ GHR locus polymorphisms had significant association with carcass components in F2 Kampung and broiler chicken cross. Here, GHR is a potential marker for carcass traits in chicken.

\section{ACKNOWLEDGEMENT}

Authors thank to PMDSU Research Grant 2016 (Batch I) from The Ministry of Research, Technology, and Higher Education, Republic of Indonesia, which financially supported this work.

\section{REFERENCES}

Abdurrahman, Z. H, Y. B. Pramono, \& N. Suthama. 2016. Meat characteristic of crossbred local chicken fed inulin of dahlia tuber and Lactobacillus sp. Med. Pet. 39:112-118. https:// doi.org/10.5398/medpet.2016.39.2.112

Al-Khatib, B. G. M. \& D. H. H. Al-Hassani. 2016. Effect of G1705A SNP in growth hormone gene on the productive and physiological performance in broiler chicken. Iraqi J. Biotech. 15:33-45.

Allendorf, F. W., G. Luikart, \& S. N. Aitken. 2013. Conservation and the Genetics of Population $2^{\text {nd }}$ Ed. Wiley-Blackwell Publishing, UK.

Anh, N. T. L., S. Kunhareang, \& M. Duangjinda. 2015. Association of chicken growth hormones and insulin-like growth factor gene polymorphisms with growth performance and carcass traits in Thai broilers. Asian-Australas. J. Anim. Sci. 28:1686-1695. http://dx.doi.org/10.5713/ ajas.15.0028.

An, X., L. Wang, J. Hou, G. Li, Y. Song, J. Wang, M. Yang, Y. Cui, \& B. Cao. 2011. Novel polymorphisms of goat growth hormone and growth hormone receptor genes and their effects on growth traits. Mol. Biol. Rep. 38: 4037. http:// dx.doi.org/10.1007/s11033-010-0522-3.

Arai, N., \& M. Iigo. 2010. Duplicated growth hormone genes in a passerine bird, the jungle crow (Corvus macrorhynchos). Biochem. Biophys. Res. Commun. 397: 553-558. http:// dx.doi.org/10.1016/j.bbrc.2010.05.156

Ashok, S. K., Y. Kuwabara, S. Abe, \& E. H. Morita. 2014. Polymorphism in growth hormone gene sequence from microminipig (MMP) with direct sequencing PCR. IJSTR. 3:83-92.

Çiftci, H. B. 2013. Estrogen and growth hormone and their roles in reproductive function. Int. J. Anim. Vet. Adv. 5: 21-28.

Dolmatova, I. Y. \&. I. G. Ilyasov. 2011. Association of cattle growth hormone gene polymorphism with milk productivity. Russ. J. Genet. 47:720-725. https://doi. org/10.1134/S1022795411060081

FAO. 2008. Local chicken genetic resources and production systems in Indonesia. Prepared by Muladno Muladno. GCP/ RAS/228/GER Working Paper No. 6. Rome.

Fulton, J. E. 2008. Molecular genetics in a modern poultry breeding organization. World's Poult. Sci. J. 64:171-176. https:// doi.org/10.1017/S0043933907001778

Gosney, E. S., A. Jara, A. Basu, \& J. J. Kopchick. 2012. GH in the central nervous system: lessons from the growth hormone receptor knockout mouse. Open Endocrinol. J. 6:34-41. http://dx.doi.org/10.2174/1874216501206010034.

Hall, T. 2011. BioEdit: An important software for molecular biology. GERF Bulletin of Biosciences 2:60-61.

Harvey, S. 2013. Growth hormone and growth? Gen. Comp. Endocrinol. 190:3-9. http://dx.doi.org/10.1016/j. ygcen.2013.01.008.

Hrabia, A., H. E. Paczoska-Eliasiewicz, L. R. Berghman, S. Harvey, \& J. Rząsa. 2008. Expression and localization of growth hormone and its receptors in the chicken ovary during sexual maturation. Cell Tissue Res. 332:317-328. http://dx.doi.org/10.1007/s00441-008-0595-7

Hull, K. L. \& S. Harvey. 2014. Growth hormone and reproduction: a review of endocrine and autocrine/paracrine interactions. Int. J. Endocrinol. 2014. http://dx.doi. org/10.1155/2014/234014

Jia, J. L., L.P. Zhang, J. P. Wu, Z. J. Ha, \& W. W. Li. 2014. Study of the correlation between GH gene polymorphism and growth traits in sheep. Genet. Mol. Res. 13: 7190-7200. https://doi.org/10.4238/2014.September.5.5

Johari, S., N. Setiati, J.H.P. Sidadolog, T. Hartatik, \& T. Yuwanta. 2013. The gene effect of growth hormone on body weight and egg production in divergent selection for five generation of Japanese quail (Coturnix coturnix japonica). Intl. J. Poult. Sci. 12:489-494. https://doi.org/10.3923/ ijps.2013.489.494

Kamenskaya, D. N., M. V. Pankova, D. M. Atopkin, \& V. A. Brykov. 2015. Fish growth-hormone genes: Evidence of functionality of paralogous genes in Levanidov's charr Salvelinus levanidovi. Mol. Biol. 49: 687. https://doi. org/10.1134/S002689331505009X

Kansaku, N., G. Hiyama, T. Sasanami, \& D. Zadworny. 2008. Prolactin and growth hormone in birds: protein structure, gene structure and genetic variation. J. Poult. Sci. 45:1-6. http://dx.doi.org/10.2141/jpsa.45.1

Khoa, D. V. A., N. T. K. Khang, N. T. Ngu, J. Matey, H. T. P. Loan, \& N. T. D. Thuy. 2013. Single nucleotide polymorphisms in GH, GHR, GHSR and insulin candidate genes in chicken breeds of Vietnam. Greener J. Agr. Sci. 3:716-724.

Kim, J. W. 2010. The endocrine regulation of chicken growth. Asian-Aust. J. Anim. Sci. 23:1668-1676. http://dx.doi. org/10.5713/ajas.2010.10329

Knízetová, H., J. Hyánek, B. Kníze, \& J. Roubícek. 1995. Comparative study of growth curves in poultry. Genet. Sel. Evol. 27:365-375. https://doi. org/10.1186/1297-9686-27-4-365

Kopchick, J. J. 2016. Lessons learned from studies with the growth hormone receptor. Growth Horm. IGF Res. 28:2125. http://dx.doi.org/10.1016/j.ghir.2015.06.003

Kopchick, J. J., E. O. List, B. Kelder, E. S. Gosney, \& D. E. Berryman. 2014. Evaluation of growth hormone (GH) action in mice: discovery of GH receptor antagonists and clinical indications. Mol. Cell Endocrinol. 386: 34-45. http://dx.doi.org/10.1016/j.mce.2013.09.004

Kuhn, E. R., L. Vleurick, M. Edery, E. Decuypere, \& V. M. Darras. 2002. Internalization of the chicken growth hormone receptor complex and its effect on biological functions. Comp. Biochem. Physiol., B: Comp. Biochem. 132:299-308. http://dx.doi.org/10.1016/S1096-4959(02)00037-4 
Lei, M., C. Luo, X. Peng, Q. Nie, D. Zhang, G. Yang, \& X. Zhang. 2007. Polymorphism of growth-correlated genes associated with fatness and muscle fiber traits in chickens. Poult. Sci. 86:835-842. http://dx.doi.org/10.1093/ps/86.5.835

Lin, S., H. Li, H. Mu, W. Luo, Y. Li, X. Jia, S. Wang, X. Jia, Q. Nie, Y. Li, \& X. Zhang. 2012. Let-7b regulates the expression of the growth hormone receptor gene in deletiontype dwarf chickens. Genomics 13:306. http://dx.doi. org/10.1186/1471-2164-13-306

List, E. O., D. E. Berryman, K. Funk, E. S. Gosney, A. Jara, B. Kelder, X. Wang, L. Kutz, K. Troike, N. Lozier, V. Mikula, E. R. Lubbers, H. Zhang, C. Vesel, R. K. Junnila, S. J. Frank, M. M. Masternak, A. Bartke, J. J. Kopchick. 2013. The role of GH in adipose tissue: lessons from adipose-specific GH receptor gene-disrupted mice. Mol. Endocrinol. 27: 524-535. http://dx.doi.org/10.1210/me.2012-1330

Moharrery, A. \& M. Mirzaei. 2014. Growth characteristics of commercial broiler and native chickens as predicted by different growth functions. J. Anim. Feed Sci. 23:82-89. http://dx.doi.org/10.22358/jafs/65720/2014

Nataamijaya, A. G. 2010. Pengembangan potensi ayam lokal untuk menunjang peningkatan kesejahteraan petani. Jurnal Litbang Pertanian 29:131-138.

Nei, M. \& S. Kumar. 2000. Molecular Evolution and Phylogenetic. Oxford University Press, New York.

Nie, Q., B. Sun, D. Zhang, C. Luo, N. A. Ishag, M. Lei, G. Yang, \& X. Zhang. 2005. High diversity of the chicken growth hormone gene and effects on growth and carcass traits. J. Heredity 96:698-703. http://dx.doi.org/10.1093/jhered/ esi114

Ouyang, J. H., L. Xie, Q. Nie, C. Luo, Y. Liang, H. Zeng, \& X. Zhang. 2008. Single nucleotide polymorphism (SNP) at the GHR gene and its associations with chicken growth and fat deposition traits. Br. Poult. Sci. 49:87-95. http://dx.doi. org $/ 10.1080 / 00071660801938817$

Padhi, M. K. 2016. Importance of indigenous breeds of chicken for rural economy and their improvements for higher production performance. Scientifica 2016. http://dx.doi. org/10.1155/2016/2604685.

Sambrook, J. \& D. Russell. 2001. Molecular Cloning: A Laboratory Manual 3rd Ed. Cold Spring Harbor Laboratory Press, USA.

SAS Institute. 2008. SAS/STAT® 9.2 User's Guide The GLM Procedure (Book Excerpt). SAS Institute Inc. Cary, NC, USA.

Sedek, M., L. M. van der Velden, \& G. J. Strous. 2014. Multimeric growth hormone receptor complexes serve as signaling platforms. J. Biol. Chem. 289:65-73. http://dx.doi. org/10.1074/jbc.M113.523373

Shawki, I., M. Mourad, M. A. Rashed, \& I. M. Ismail. 2015. Molecular characterization of camel growth hormone gene in maghraby camel breed. Animal Science Reporter 9: 50-55.
Sheng, Z., M. E. Pettersson, X. Hu, C. Luo, H. Qu, D. Shu, X. Shen, Ö. Carlborg, \& N. Li. 2013. Genetic dissection of growth traits in a Chinese indigenous $\times$ commercial broiler chicken cross. Genomics 14:151. http://dx.doi. org/10.1186/1471-2164-14-151.

Stephen, C. Y. I., X. Zhang, \& F. C. Leung. 2001. Genomic growth hormone gene polymorphisms in native Chinese chickens. Exp. Biol. Med. 226: 458. https://doi. org/10.1177/153537020122600511

Su, Y. J., J. T. Shu, M. Zhang, X. Y. Zhang, Y. J. Shan, G. H. Li, J. M. Yin, W. T. Song, H. F. Li, \& G. P. Zhao. 2014. Association of chicken growth hormone polymorphisms with egg production. Genet. Mol. Res. 13: 4893-4903. https://doi.org/10.4238/2014.July.4.3

Tamura, K., G. Stecher, D. Peterson, A. Filipski, \& S. Kumar. 2013. MEGA6: Molecular Evolutionary Genetics Analysis Version 6.0. Mol. Biol. Evol. 30:2725-2729. https://doi. org $/ 10.1093 / \mathrm{molbev} / \mathrm{mst} 197$

van den Eijnden, M. J. \& G. J. Strous. 2007. Autocrine growth hormone: effects on growth hormone receptor trafficking and signaling. Mol. Endocrinol. 21:2832-2846. http:// dx.doi.org/10.1210/me.2007-0092

Vu, C. T., \& N. T. Ngu. 2016. Single nucleotide polymorphisms in candidate genes associated with egg production traits in native noi chicken of Vietnam. IJPAES. 6:162-169.

Xu, Z., Q. Nie, \& X. Zhang. 2013. Overview of genomic insights into chicken growth traits based on genome-wide association study and microRNA regulation. Curr. Genomics 14:137-146. http://dx.doi.org/10.2174/138920291131402000 6.

Yurnalis, Husmaini, \& Sabrina. 2017. Polymorphisms of growth hormone gene exon 1 and their associations with body weight in Pitalah and Kumbang Janti ducks. Intl. J. Poult. Sci. 16:203-208. https://doi.org/10.3923/ijps.2017.203.208

Yuwanta, T. \& N. Fujihara. 2000. Indonesian native chickens: Production and reproduction potentials and future development. British Poul. Sci. 41:25-25. https://doi. org/10.1080/00071660050148624

Zein, M. S. A. \& S. Sulandari. 2012. Genetic diversity and haplogroups distributions of Kampung chickens using hypervariable-I mitochondrial DNA control region. JITV 17: 120-131.

Zhang, X. L., X. Jiang, Y. P. Liu, H. R. Du, \& Q. Zhu. 2007. Identification of AvaI polymorphisms in the third intron of GH gene and their associations with abdominal fat in chickens. Poult. Sci. 86:1079-1083. http://dx.doi. org/10.1093/ps/86.6.1079

Zhang, Y, Z. Zhu, Q. Xu, \& G. Chen. 2014. Association of polymorphisms of exon 2 of the growth hormone gene with production performance in Huoyan goose. Int. J. Mol. Sci. 15:670-683. https://doi.org/10.3390/ijms15010670 